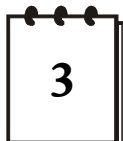

\title{
Respon Komunitas Nelayan terhadap Modernisasi Perikanan

\author{
(Studi Kasus Nelayan Suku Bajo di Desa Lagasa, Kabupaten
} Muna, Propinsi Sulawesi Tenggara $)^{1}$
}

\author{
Awaluddin Hamzah ${ }^{2}$, Nurmala K. Pandjaitan ${ }^{3}$, Nuraini W. Prasodjo ${ }^{4}$
}

\begin{abstract}
Ringkasan
Modernisasi melalui peningkatan dan penggunaan teknologi alat tangkap serta bantuan permodalan berimplikasi pada kegiatan serta organisasi penangkapan ikan dan pada akhirnya terjadi perubahan dalam suatu komunitas. Tidak semua lapisan nelayan dapat memanfaatkan peluang modernisasi. Sebelum program modernisasi perikanan, struktur komunitas nelayan Suku Bajo masih didominasi oleh sistem perikanan tradisional, kegiatan dicirikan struktur komunitas homogen dan tingkat diferensiasi sosial yang masih rendah. Berbagai ukuran yang dapat dilihat menunjukan bahwa nelayan tergolong tidak sejahtera. Pemerintah memandang perlu untuk memperbaiki taraf hidup nelayan. Realisasinya dilakukan antara lain dalam bentuk modernisasi perikanan (Revolusi Biru). Penerimaan maupun penolakan suatu hal baru berkaitan dengan proses mental sejak seseorang mengetahui adanya inovasi. Proses tersebut bagi nelayan tidak terlepas dari pengaruh pemaknaan terhadap laut serta pekerjan nelayan bagi nelayan itu sendiri.
\end{abstract}

Hasil penelitian menunjukan kecenderungan terjadi bahwa Pengadopsi Cepat (PC) memiliki karakteristik yang lebih baik dibandingkan adopter yang lebih lambat. Pada pemaknaan laut, kebanyakan responden memberi makna ekonomi, psikologi dan budaya yang positif. Sedangkan pada makna pekerjaan nelayan kebanyakan responden memberi makna ekonomi, sosiologis, teologis, dan budaya yang cenderung positif. Selain itu nampaknya terdapat hubungan antara pemaknaan dengan kecepatan adopsi. Hubungan tersebut adalah semakin positif makna ekonomis maka adopsi inovasi semakin cepat. Sebaliknya semakin positif makna budaya kecenderungan adopsi cenderung semakin lambat. Modernisasi perikanan berdampak pada perubahan pola kerja yakni daya jelajah lebih jauh, jumlah pekerja (sawi) lebih banyak dengan sifat semi bebas dan perekrutan lebih selektif. Pembagian kerja lebih jelas dan berjenjang serta hierarkis. Terjadi pula dampak perubahan struktur sosial dengan sistem bagi hasil yang menjadi pranata nelayan, stratifikasi yang kompleks, diferensiasi beragam, dan pola hubungan non eksploitatif. Dampak teknologi gae juga menghasilkan peningkatan pemenuhan kebutuhan dasar serta gizi anggota keluarga nelayan serta kesadaran pentingnya pendidikan bagi anggota keluarga.

Kata kunci: Respon modernisasi, komunitas nelayan, nelayan Suku Bajo.

\section{Pendahuluan}

\subsection{Latar Belakang}

\footnotetext{
Hasil Penelitian

Pengajar pada Jurusan Sosek Fakultas Pertanian Universitas Haluoleo, Kendari

3 Pengajar pada Dep Komunikasi Pengembangan Masyarakat Fakultas Ekologi Manusia IPB

4 Pengajar pada Dep Komunikasi Pengembangan Masyarakat Fakultas Ekologi Manusia IPB
} 
Indonesia merupakan sebuah negara yang memiliki beragam suku bangsa yang menyebar dan menetap pada berbagai pulau besar maupun pulau-pulau kecil yang membentang dari Sabang sampai Merauke. Mereka mendiami wilayahwilayah tersebut secara turun-temurun dengan kebudayaan, kelembagaan, serta sistem sosial dan ekonomi lainnya masing-masing.

Aktivitas ekonomi tersebut tidak lepas dari interaksi antarindividu serta kelompok internetnis tersebut. Dalam interaksi internmasyarakat dalam satu etnis telah menimbulkan proses sosial dalam masyarakat itu sendiri. Geertz dalam Mubyarto et al. (1993) mencatat di Indonesia terdiri dari kurang lebih 300 etnik (suku bangsa) dengan kebudayaannya sendiri-sendiri, dengan 250 bahasa daerah yang berbeda.

Sebagian suku mendiami kawasan sekitar hutan, yang mengandalkan hidup sebagai petani ladang berpindah atau menggantungkan diri dengan memungut hasil hutan yang menyebabkan mereka hidup terisolasi. ${ }^{5}$ Sebagian pula bahkan dalam kuantitas besar masyarakat tinggal dan hidup di daerah pantai dan pesisir, dengan kegiatan ekonomi, sosial dan budaya yang tidak lepas dari laut (nelayan). Kondisi geografis ekologis desa pesisir mempengaruhi aktivitas ekonomi di dalamnya.

Secara geografis, letak kepulauan Nusantara (Indonesia) sangat strategis dalam konteks perdagangan laut internasional antara dunia Barat dan Timur. Pada berbagai wilayah tersebut laut merupakan penghubung antara pulau-pulau tersebut disamping sebagai tempat utama kegiatan penangkapan ikan serta hasil laut lainnya oleh nelayan. Kusumastanto (2002) mencatat di Indonesia terdapat 42 kota dan 181 kabupaten terletak di kawasan pesisir. Sumberdaya ikan sebagai bahan konsumsi $90 \%$ berasal dari wilayah pesisir. Sementara Syam dalam Suhartini, et al. (2005) memperkirakan luas wilayah maritim Indonesia mencapai 5,8 juta $\mathrm{Km}^{2}$ dan dapat menjadi potensi sumber daya kelautan sebagai salah satu tumpuan harapan masa depan.

Winahyu dan Santiasi dalam Mubyarto et al. (1993) menambahkan dengan membandingkan masyarakat desa pesisir dengan masyarakat lain, nelayan merupakan lapisan yang paling miskin, dibanding dengan komunitas di luar pesisir. Pendapatan yang diperoleh nelayan sifatnya harian dan jumlahnya tidak bisa ditentukan. Selain itu pendapatannya berfluktuasi ditentukan oleh musim serta status nelayan itu sendiri (pemilik kapal atau anak buah).

Berdasarkan ukuran yang dapat dilihat dari rumah tempat tinggal, pakaian, pemenuhan gizi, gaya hidup (life style), status sosial, secara umum nelayan tergolong tidak sejahtera. Pada komunitas nelayan terdapat lingkungan hidup yang kumuh serta rumah-rumah yang sangat sederhana. Hanya sebagian kecil nelayan yang memiliki rumah yang relatif bagus, dan rumah-rumah tersebut umumnya dipunyai oleh pemilik kapal, pemodal, atau rentenir.

Djatmiko, E, Karakteristik dan Permasalahan Pedesaan di Indonesia, dalam Mubyarto (Eds). 1993. Dua Puluh Tahun Penelitian Pedesaan. Yogyakarta: Aditya Media. 
Pemerintah memandang perlu untuk memperbaiki taraf hidup nelayan. Usaha tersebut didukung pula oleh pihak pengusaha dalam melihat potensi bisnis perikanan. Realisasinya dilakukan antara lain dalam bentuk modernisasi perikanan (Revolusi Biru) oleh pemerintah dan swasta. Modernisasi yang dilakukan oleh pemerintah dan pihak lain dimaksudkan sebagai bentuk perhatian serta peningkatan kesejahteraan nelayan disamping untuk peningkatan produksi sebagai pemenuhan kebutuhan ikan dalam konteks nasional maupun regional dan lokal. Program tersebut antara lain berupa bantuan modifikasi sarana penangkapan, pemberian kredit bergulir masyarakat pesisir, serta penyuluhan lingkungan pesisir dan lautan.

Pada dasarnya setiap program yang bersentuhan langsung dengan masyarakat akan berdampak pada nilai dan norma serta budaya lokal. Demikian pula dengan kelestarian lingkungan laut dan pantai sebagai sumber utama kegiatan nelayan. Hampir seluruh pelaku program berasal dari luar komunitas yang terkadang tidak memikirkan nilai dan norma dalam suatu komunitas, kecuali hanya menjalankan dan mencapai tujuan program. Gejala tersebut ditambah dengan kemudahan akses komunikasi dan informasi yang sangat mudah dapat menggeser nilai ideal menjadi nilai aktual / kenyataan (actual values). ${ }^{6}$

Kehidupan nelayan utamanya lapisan buruh dalam kegiatan produksinya (penangkapan ikan) sebagian besar tergantung dari hubungan baik dengan pihak juragan (pemilik kapal). Hal tersebut dikarenakan kekurangan ataupun ketiadaan modal finansial yang memadai. Kekurangan modal tersebut semakin menambah beban dan tantangan serta persaingan yang besar dalam hal pemanfaatan sumberdaya laut. Di satu sisi nelayan buruh dengan kemampuan serta keterampilan menangkap ikan adalah potensi, di sisi lain tidak adanya modal adalah kendala, mengingat wilayah laut adalah wilayah terbuka yang dapat dimanfaatkan oleh siapa saja yang memiliki kemampuan untuk mengelola sumberdaya yang ada di dalamnya.

Intervensi / pembangunan ditanggapi beragam oleh berbagai kelompok masyarakat maupun tingkatan stratifikasi nelayan. Dalam komunitas nelayan perubahan yang nampak adalah berubahnya pola kerja, sistem stratifikasi baik karena dasar penguasaan alat produksi maupun mencakup pula kekuasaan. Perubahan stratifikasi juga terjadi pada organisasi penangkapan sebagai implikasi dari alih teknologi tersebut, sehingga kelembagaan nelayan yang telah terbangun sebelumnya biasanya akan terjadi perubahan pula. Terjadi pula diversifikasi usaha sebagai dampak dari alih teknologi (Satria, 2001) dimana dalam penelitian ini dimasukkan sebagai item modernisasi sektor perikanan.

Modernisasi melalui peningkatan dan penggunaan teknologi alat tangkap serta bantuan permodalan berimplikasi pada kegiatan serta organisasi penangkapan ikan dan pada akhirnya terjadi perubahan dalam suatu komunitas. Program motorisasi

6 Wirutomo (2005) membagi gejala menonjol dari proses perkembangan nilai di Indonesia adalah antara lain jurang antara nilai ideal dan nilai aktual. 
perahu dan modernisasi perikanan tangkap pada 1980 -an yang dikenal dengan istilah Revolusi Biru, menurut Solihin (2005) bukannya menciptakan perikanan tambah maju dan pelakunya (nelayan) menjadi sejahtera.

Hal tersebut menjadi perhatian karena tidak semua lapisan nelayan dapat memanfaatkan peluang modernisasi. Sebelum program modernisasi perikanan oleh pemerintah, nelayan Suku Bajo masih didominasi oleh sistem perikanan tradisional, dimana salah satu cirinya adalah struktur komunitas homogen dan tingkat diferensiasi sosial yang masih rendah. Kehidupan sosial nelayan Suku Bajo setelah berlangsungnya modernisasi menjadi fokus kajian dalam penelitian ini.

Di samping itu nelayan sebagai pihak yang menggunakan teknologi sebagai bagian dari modernisasi tersebut dihadapkan pada suatu pilihan untuk mengadopsi atau tidak mengadopsi teknologi tersebut. Berbagai faktor yang mempengaruhi adopsi tersebut antara lain adalah bagaimana nelayan tersebut memaknai laut serta pekerjaan nelayan yang digeluti selama ini. Pemaknaan tersebut sangat penting oleh karena mencakup cara pandang mereka terhadap sesuatu / obyek yang berkaitan langsung dengan mata pencaharian mereka pada berbagai aspek yakni aspek ekonomi, sosial (sosiologis), religius (teologis), psikologis serta budaya.

Suku Bajo sejak dulu telah menempati laut, pesisir dan kepulauan, bahkan terkesan mereka tidak bisa melangsungkan aktivitasnya di daratan dibanding dengan suku lain seperti Bugis-Makassar yang mampu menyelenggarakan kehidupannya di semua tempat. Hampir setiap program modernisasi berdampak pada kehidupan serta sistem sosial dalam suatu komunitas tertentu. Suku Bajo mayoritas bekerja sebagai nelayan secara turun-temurun. Oleh karena kehidupan Suku Bajo sangat dekat dengan laut, maka suatu hal yang perlu dikaji bahwa bagi mereka nelayan dan laut dapat dipandang sebagai budaya, sumber mencari nafkah ataupun sarana pelestarian lingkungan laut dan pesisir. Dinamika kehidupan yang sangat sulit dipisahkan dengan laut, membuat kajian tentang suku Bajo termasuk dari sisi kehidupan sosial menjadi menarik.

Kajian Peribadi (2000) antara lain menyimpulkan bahwa dalam hal usaha mata pencaharian telah terjadi pergeseran dari orientasi sosial kepada orientasi ekonomi. Penelitian lainnya juga dilakukan oleh Wunawarsih (2005) dan mendukung hal tersebut dan menghasilkan kesimpulan relokasi penduduk menyebabkan terjadinya mobilitas vertikal contohnya peralihan posisi sawi menjadi ponggawa. Berbagai program pembangunan perikanan dan kelautan telah menyentuh dan berdampak langsung maupun tidak langsung terhadap kehidupan komunitas Suku Bajo.

\subsection{Tujuan Penelitian}

Masuknya program modernisasi pada komunitas Suku Bajo jelas bersentuhan dengan nilai budaya, gaya hidup, dan di satu sisi berdampak pada efektivitas dan peningkatan hasil tangkapan nelayan. Alih teknologi dapat dipastikan menaikkan produksi dan pendapatan nelayan. Akan tetapi dampak sosiologis ketika 
modernisasi akan diterapkan maupun sedang diterapkan perlu dikaji dalam kerangka komunitas nelayan Suku Bajo.

Berdasarkan berbagai uraian tersebut tujuan penelitian ini adalah untuk mengetahui:

(1) Hubungan makna laut dan makna pekerjaan nelayan dengan penerimaan Suku Bajo terhadap modernisasi perikanan.

(2) Dampak Modernisasi Perikanan pada komunitas nelayan Suku Bajo (pola kerja nelayan, struktur sosial, dan tingkat kesejahteraan)

\subsection{Kerangka Pemikiran}

Kemiskinan dan kesenjangan sosial pada kehidupan nelayan menjadi salah satu perhatian utama bagi kebijakan sektor perikanan. Menurut pemerintah bahwa kemiskinan dan keterbelakangan nelayan antara lain disebabkan karena hasil tangkapan yang sangat kecil sementara stok ikan masih sangat melimpah. Kecilnya hasil tangkapan tersebut antara lain disebabkan karena penggunaan sarana tangkap yang kurang memadai yakni dengan menggunakan teknologi sederhana. Teknologi sederhana tersebut hanya dapat menjangkau wilayah pinggir pantai dengan populasi ikan yang sangat terbatas.

Pemerintah memandang perlu untuk memperbaiki taraf hidup nelayan. Realisasinya dilakukan antara lain dalam bentuk modernisasi perikanan (Revolusi Biru). Hal penting modernisasi perikanan adalah melalui perbaikan teknologi kapal atau alat tangkap untuk peningkatan produksi. Salah satu aspek penting dari modernisasi bidang perikanan ini adalah substitusi teknik produksi dari cara-cara tradisional kepada cara yang lebih rasional. Perihal kebijakan modernisasi ini diharapkan terjadi peningkatan produktivitas yang dampkanya secara langsung dapat memperbaiki kesejahteraan nelayan.

Suatu hal yang sangat mempengaruhi keputusan adopsi dalam konteks nelayan adalah sejauhmana mereka memaknai laut dan pekerjaan nelayan. Variabel yang mempengaruhi makna adalah faktor sosial ekonomi individu dalam hal ini karakteristik seseorang, faktor lingkungan berupa kondisi alam, kebijakan pemerintah maupun sosial budaya masyarakat serta hubungan dan keterlibatan pada obyek antara individu dengan obyek yang dimaknai. Dalam konteks nelayan, hubungan dengan laut dan pekerjaan sebagai nelayan terkait dengan pengalaman usaha menangkap ikan, lamanya tinggal dan menetap di pantai serta kepentingan terhadap laut dan pekerjaan nelayan itu sendiri.

Salah satu tipe keputusan adopsi inovasi adalah tipe keputusan inovasi oleh otoritas. Pada kasus kelompok nelayan, keputusan adopsi menjadi otoritas pemilik sarana produksi dalam hal ini ponggawa. Dalam hal ini pemaknaan terhadap laut dan pekerjaan nelayan dimasukkan sebagai salah satu faktor internal (individu) dalam variabel yang mempengaruhi keputusan tersebut.

Makna laut dan makna pekerjaan nelayan mengandung pemahaman tentang sejauhmana arti laut dan nelayan dalam kehidupan nelayan itu sendiri. Makna diperoleh melalui interaksi sosial yang dialami oleh seseorang. Selain itu, dalam 
pemaknaan individu terhadap suatu simbol terdapat beberapa faktor yang mempengaruhi pola pikir (pemahaman simbol) yang mengarahkan perilaku seseorang antara lain: sifat alamiah individu, pengalaman, pengetahuan, budaya dan struktur sosial masyarakat tempat individu itu tinggal. Di samping itu dalam konteks nelayan, variabel penting penilaian terhadap laut yakni: (a) tingkat kepentingan; (b) produktivitas, dalam arti mudah tidaknya proses distribusi berjalan serta (c) sistem kepercayaan terhadap laut itu sendiri. Oleh karena itu pemaknaan terhadap laut dan pekerjaan nelayan dipengaruhi oleh faktor individu dan faktor lingkungan.

Modernisasi perikanan berdampak pada kehidupan sosial nelayan maupun komunitas nelayan tersebut. Dampak tersebut adalah perubahan pola kerja dari penggunaan teknologi lama yang masih sederhana menjadi teknologi baru yang lebih modern, efektif dan efisien. Efektivitas dan efisiensi modernisasi tersebut menimbulkan diferensiasi yakni munculnya unit-unit sosial baru yang berdampak pada perubahan struktur sosial nelayan. Perubahan struktur tersebut terjadi pada level nelayan maupun komunitas. Pada level nelayan, diferensiasi tersebut menimbulkan nelayan terstratifikasi dalam beberapa lapisan. Perubahan lapisan nelayan tersebut jelas berdampak pada perubahan stratifikasi pada level komunitas sehingga struktur sosial menjadi berubah. Pola kerja lebih efisien tersebut juga berdampak pada perolehan tangkapan yang mempengaruhi pendapatan nelayan. Oleh karena itu modernisasi berupa alih teknologi tersebut juga berdampak pada kesejahteraan nelayan.

Penggunaan / penerapan teknologi berdampak pada pola kerja, struktur sosial maupun tingkat kesejahteraan nelayan yang berbeda baik pada teknologi lama maupun teknologi baru. Pada penggunaan teknologi lama, pola kerja dengan dimensi daya jelajah lebih dekat, waktu melaut lebih singkat, jumlah pekerja lebih kecil serta pembagian kerja tidak ada atau ada tetapi tidak jelas. Sedangkan penggunaan tekologi baru (modernisasi) pola kerja pada dimensi daya jelajah lebih jauh, waktu melaut lebih panjang, jumlah pekerja lebih banyak serta pembagian kerja menjadi lebih jelas.

Sebelum penggunaan teknologi (modernisasi), dalam hal struktur sosial, dengan dimensi diferensiasi belum beragam, stratifikasi pada konteks komunitas berdasarkan kehormatan dan pekerjaan (ascribed and achieved status) serta pola hubungan noneksplotatif dan egaliter pada penggunaan teknologi lama. Sedangkan pada penggunaan teknologi baru (modernisasi) diferensiasi lebih beragam, stratifikasi lebih didasarkan pada achieved status serta pola hubungan semieksploitatif serta hierarkis. Sedangkan perubahan tingkat kesejahteraan tergambar bahwa peningkatan pendapatan cukup tinggi terjadi pada nelayan ponggawa. Nelayan dengan status sawi, peningkatan pendapatan tidak signifikan.

Secara ringkas, alur kerangka pemikiran penelitian ini dapat digambarkan sebagai berikut: 


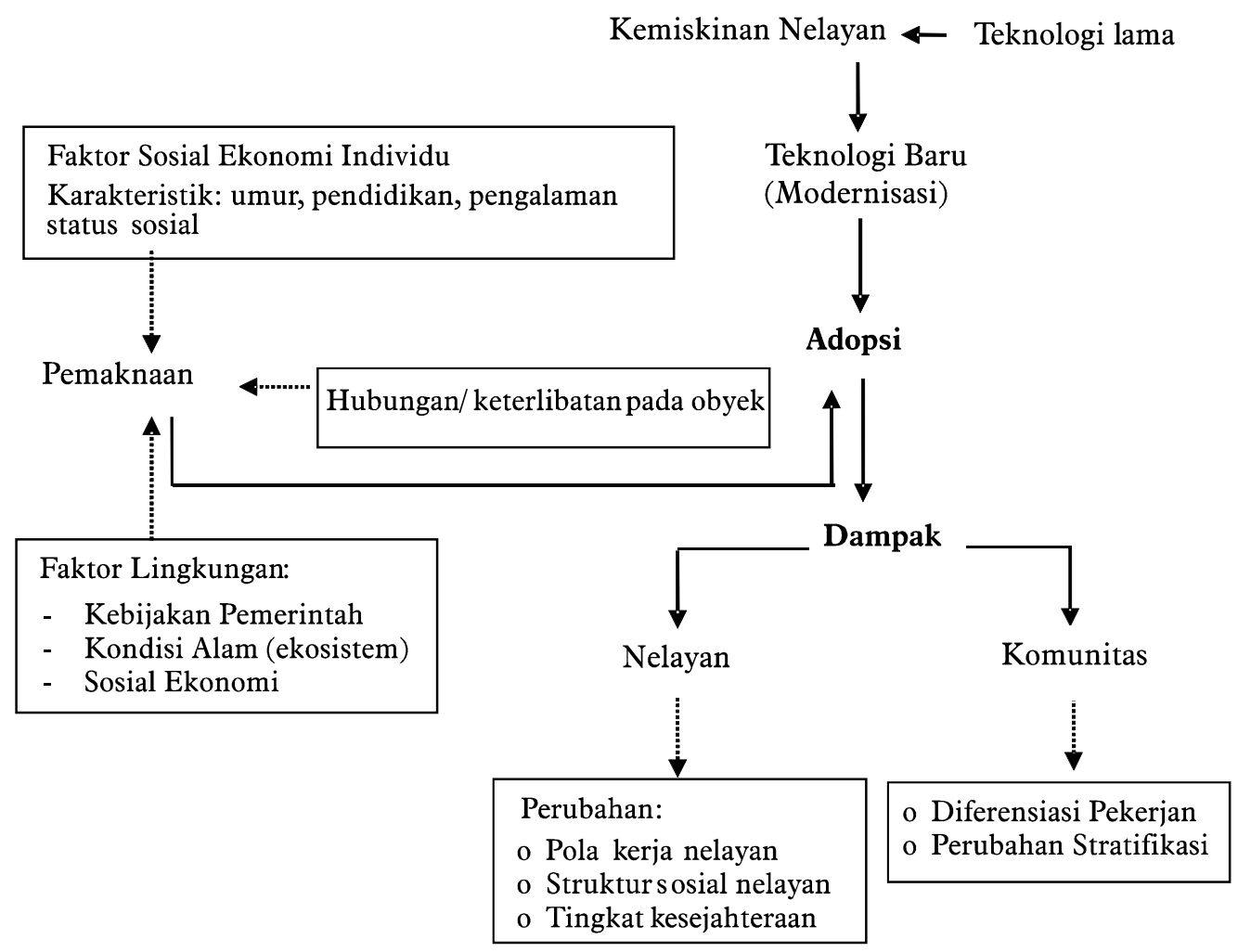

\section{Keterangan:}

$\longrightarrow$ : Mempengaruhi,

$\rightarrow$........ : Variabel

Gambar 1. Alur kerangka pemikiran penelitian respon komunitas nelayan terhadap Modernisasi Perikanan

\section{Hasil dan Pembahasan}

\subsection{Lokasi dan Responden}

Penelitian dilaksanakan pada bulan Juli sampai dengan September 2007, di Desa Lagasa, Kecamatan Duruka, Kabupaten Muna, Propinsi Sulawesi Tenggara.

Setelah dilakukan pengkategorian, maka diperoleh sampel sebanyak 100 responden masing-masing: nelayan ponggawa sebanyak 45 orang, nelayan sawi lokal sebanyak 30 orang, nelayan sawi luar desa sebanyak 25 orang. Informan dalam penelitian ini yaitu: (a) Kepala Desa, (b) seorang mantan Kepala Desa, (c) Pensiunan Dinas Perikanan Muna berdomisili di Desa Lagasa (d) Pegawai TPI, (e) Seorang mantan ponggawa. 


\subsection{Metode Pengumpulan Data}

Metode yang digunakan untuk mengumpulkan data primer dari sumber informasi adalah dengan:

1. Isian kuesioner

2. Wawancara dengan informan maupun responden

3. Pengamatan langsung (observasi partisipasi)

\subsection{Analisis Data}

Analisis data dilakukan secara deskriptif yakni pengembangan konsep dan menghimpun fakta tetapi tidak melakukan pengujian hipotesa, serta analisis hubungan antarvariabel untuk uji hipotesa dengan menggunakan pendekatan kuantitatif dan kualitatif. Terhadap data kuantitatif primer, dilakukan pengolahan dengan menggunakan tabel frekuensi dan tabulasi silang sederhana. Hasil Analisis disimpulkan dengan diperkaya hasil wawancara mendalam serta observasi untuk lebih memahami dan mendalami data yang diperoleh melalui kuesioner. Analisis data kualitatif dilakukan dengan tahapan reduksi dan penyajian data. Selanjutnya dilakukan penyajian data dalam bentuk tulisan.

\subsection{Respon terhadap Modernisasi}

Modernisasi berupa alih teknologi kapal dan alat tangkap masuk di Desa Lagasa tahun 1976-1977. Berdasarkan jumlah adopter, sebaran responden pada tahun 1981 nelayan mulai mengadopsi teknologi. Pengadopsi Cepat (PC) terdiri dari 15 (33.3 persen) responden, Pengadopsi Sedang (PS) terdapat 14 (31.1 persen), dan Pengadopsi Lambat (PL) sebanyak 16 (35.6 persen). Dari jumlah tersebut terlihat bahwa kecenderungan adopter semakin banyak untuk Pengadopsi Lambat (PL) dibanding jumlah adopter sebelumnya.

Penilaian positif pada makna laut untuk nelayan dengan status ponggawa lebih banyak pada makna ekonomis dan makna budaya. Tingginya persentase penilaian positif makna budaya menunjukkan bahwa nelayan masih menempatkan laut dalam kerangka kepentingan nilai-nilai budaya yang sama pentingnya dengan kepentingan ekonomis.

Kecenderungan terjadi bahwa Pengadopsi Cepat (PC) memiliki karakteristik yang lebih baik dibandingkan adopter yang lebih lambat. PC memiliki umur lebih muda, pengalaman lebih banyak pendapatan lebih tinggi serta pendidikan lebih lama dibanding katagori adopter lainnya.

Pada pemaknaan laut, kebanyakan responden memberi makna ekonomi, psikologi, dan budaya yang positif. Sedangkan pada makna pekerjaan nelayan kebanyakan responden memberi makna ekonomi, sosiologis, teologis, dan budaya yang cenderung positif. Sementara untuk makna psikologis, sosiologis dan budaya memperlihatkan tidak ada perbedaan antara ketiga adopter dengan perkataan lain baik pengadopsi cepat, pengadopsi sedang, maupun pengadopsi 
lambat memaknai laut dan pekerjaan nelayan positif baik aspek sosiologis, psikologis, dan budaya.

Selain itu nampaknya terdapat hubungan antara pemaknaan dengan kecepatan adopsi. Hubungan tersebut adalah semakin positif makna ekonomis maka adopsi inovasi semakin cepat. Sebaliknya semakin positif makna budaya kecenderungan adopsi cenderung semakin lambat.

Adapun jumlah dan persentase responden berdasarkan aspek makna laut adalah sebagai berikut:

Tabel 1 Sebaran responden Ponggawa setiap kategori makna Laut

\begin{tabular}{|c|c|c|c|c|c|c|c|c|c|c|c|c|}
\hline \multirow{3}{*}{ Makna Laut } & \multicolumn{4}{|c|}{$P C(n=15)$} & \multicolumn{4}{|c|}{$P S(n=14)$} & \multicolumn{4}{|c|}{$\mathrm{PL}(\mathrm{n}=16)$} \\
\hline & \multicolumn{2}{|c|}{ Positif } & \multicolumn{2}{|c|}{ Negatif } & \multicolumn{2}{|c|}{ Positif } & \multicolumn{2}{|c|}{ Negatif } & \multicolumn{2}{|c|}{ Positif } & \multicolumn{2}{|c|}{ Negatif } \\
\hline & $\mathrm{Jml}$ & $\%$ & $\mathrm{Jml}$ & $\%$ & $\mathrm{Jml}$ & $\%$ & $\mathrm{Jml}$ & $\%$ & $\mathrm{Jml}$ & $\%$ & $\mathrm{Jml}$ & $\%$ \\
\hline Ekonomis & 14 & 93 & 1 & 7 & 12 & 86 & 2 & 14 & 13 & 81 & 3 & 19 \\
\hline Sosiologis & 9 & 60 & 6 & 40 & 8 & 57 & 6 & 43 & 8 & 50 & 8 & 50 \\
\hline Teologis & 10 & 67 & 5 & 33 & 9 & 64 & 5 & 36 & 11 & 69 & 5 & 31 \\
\hline Psikologis & 11 & 73 & 4 & 27 & 11 & 79 & 3 & 21 & 11 & 69 & 5 & 31 \\
\hline Budaya & 13 & 87 & 2 & 13 & 12 & 86 & 2 & 14 & 14 & 88 & 2 & 13 \\
\hline
\end{tabular}

Sedangkan jumlah dan persentase responden berdasarkan aspek makna pekerjaan nelayan adalah sebagai berikut:

Tabel 2 Sebaran responden Ponggawa setiap kategori makna Nelayan

\begin{tabular}{|c|c|c|c|c|c|c|c|c|c|c|c|c|}
\hline \multirow{3}{*}{ Makna Laut } & \multicolumn{4}{|c|}{$\mathrm{PC}(\mathrm{n}=15)$} & \multicolumn{4}{|c|}{$\mathrm{PS}(\mathrm{n}=14)$} & \multicolumn{4}{|c|}{$\mathrm{PL}(\mathrm{n}=16)$} \\
\hline & \multicolumn{2}{|c|}{ Positif } & \multicolumn{2}{|c|}{ Negatif } & \multicolumn{2}{|c|}{ Positif } & \multicolumn{2}{|c|}{ Negatif } & \multicolumn{2}{|c|}{ Positif } & \multicolumn{2}{|c|}{ Negatif } \\
\hline & $\mathrm{Jml}$ & $\%$ & $\mathrm{Jml}$ & $\%$ & $\mathrm{Jml}$ & $\%$ & $\mathrm{Jml}$ & $\%$ & $\mathrm{Jml}$ & $\%$ & $\mathrm{Jml}$ & $\%$ \\
\hline Ekonomis & 15 & 100 & 0 & 0 & 14 & 100 & 0 & 0 & 14 & 88 & 2 & 13 \\
\hline Sosiologis & 12 & 80 & 3 & 20 & 10 & 71 & 4 & 29 & 12 & 75 & 4 & 25 \\
\hline Teologis & 12 & 80 & 3 & 20 & 11 & 79 & 3 & 21 & 12 & 75 & 4 & 25 \\
\hline Psikologis & 11 & 73 & 4 & 27 & 10 & 71 & 4 & 29 & 11 & 69 & 5 & 31 \\
\hline Budaya & 13 & 87 & 2 & 13 & 12 & 86 & 2 & 14 & 14 & 88 & 2 & 13 \\
\hline
\end{tabular}

\subsection{Dampak Modernisasi Perikanan}

Nelayan di Desa Lagasa menggunakan berbagai jenis sarana tangkap berupa perahu dan alat tangkap. Penggunaan berbagai sarana tangkap tersebut terdiri dari perahu tradisional dengan penggerak dayung (boseh) dalam istilah lokal koli-koli, dengan alat tangkap pancing atau jaring tassi. Selanjutnya nelayan menggunakan perahu layar motor (ngkuru-ngkuru), dengan alat tangkap pancing dan jaring tassi (pukat tassi), dan sarana modernisasi berupa penerapan teknologi kapal mini pursein 5 - 10 GT dengan alat tangkap pukat cincin (gae). 
Penggunaan setiap jenis sarana tersebut menimbulkan konsekuensi atau dampak yang terjadi yakni pola kerja, struktur sosial, serta tingkat kesejahteraan nelayan. Oleh karena itu setiap peralihan penggunaan sarana tersebut menimbulkan perubahan pula pada pola kerja, struktur sosial, serta tingkat kesejahteraan nelayan itu sendiri. Hasil tangkapan yang diperoleh juga berbeda-beda. Pada penggunaan koli-koli hasil yang diperoleh tidak terlalu banyak oleh karena jangkauan melaut hanya pada pinggiran pantai. Pada periode selanjutnya hasil yang diperoleh lebih bisa lebih banyak karena ketergantungan terhadap tenaga fisik nelayan dapat dibantu oleh mesin.

Tabel 3. Perubahan pola kerja penggunaan jenis sarana tangkap

\begin{tabular}{lccc}
\hline \multirow{2}{*}{ Dimensi } & \multicolumn{3}{c}{ Jenis Sarana Tangkap } \\
\cline { 2 - 4 } & Koli-Koli & Ngkuru-ngkuru & Gae \\
\hline Daya Jelajah & inshore & inshore & offshore \\
\hline Jumlah Pekerja $($ Sawi $)$ & $2-3$ orang & 3 - 4 orang & $12-15$ orang \\
\hline a. Sifat & Bebas & Bebas & Semi bebas \\
\hline b. Pola rekrutmen & Spontan, Komunal & Spontan, Komunal & Selektif \\
\hline Waktu Melaut & $\leq 7$ jam per hari & $\leq 7$ jam per hari & $>12$ jam per hari \\
\hline Pembagian Kerja & Tidak ada & Ada, kurang jelas & Jelas \\
\hline
\end{tabular}

Dari segi efisiensi, pekerjaan sawi menjadi lebih ringan dibandingkan ketika menggunakan teknologi lama. Pada masa sebelumnya nelayan memperhitungkan resiko tenaga serta jarak yang sukar dijangkau. Pekerjaan lebih santai, tidak memerlukan tenaga untuk mendayung, serta tidak memerlukan perawatan pukat yang sering seperti jaring kecil sebelumnya.

Implikasi peralihan setiap jenis sarana tangkap adalah berubahnya struktur sosial nelayan. Perubahan ditandai oleh munculnya diferensiasi pekerjaan sebagai konsekuensi penggunaan mesin / motor. Berbagai posisi kerja menyebabkan nelayan terstratifikasi dalam berbagai jenis lapisan. Selain itu terjadinya perubahan pola hubungan menjadi hirarkis tetapi tidak mengarah pada eksploitatif.

Tabel 4 Perubahan struktur sosial pada penggunaan jenis sarana tangkap

Dimensi $\quad$ Sarana Tangkap




\begin{tabular}{|c|c|c|c|}
\hline & Koli-Koli & Ngkuru-ngkuru & Gae \\
\hline Diferensiasi & $\begin{array}{l}\text { 1. Ponggawa, } \\
\text { 2. Sawi }\end{array}$ & $\begin{array}{l}\text { 1. Ponggawa, } \\
\text { 2. Sawi } \\
\text { 3. Tukang lume }\end{array}$ & $\begin{array}{l}\text { 1.Nakhoda / ponggawa, } \\
\text { 2. Bas, 3.Pakacca, } \\
\text { 4. Tukang listrik, } \\
\text { 5.Tukang lingkar, } \\
\text { 6.Tukang tare, } \\
\text { 7.Tukang bage, } \\
\text { 8.Tukang lume }\end{array}$ \\
\hline \multicolumn{4}{|l|}{ Stratifikasi } \\
\hline \multicolumn{4}{|l|}{ 1. Nelayan } \\
\hline a Jenis Lapisan & $\begin{array}{l}\text { Atas } \\
(\text { Ponggawa), } \\
\text { Bawah }(\text { Sawi })\end{array}$ & $\begin{array}{l}\text { Atas (ponggawa) } \\
\text { Bawah (sawi, } \\
\text { tukang lume) }\end{array}$ & $\begin{array}{l}\text { Atas (Ponggawa) } \\
\text { Menengah (Bas, tukang } \\
\text { lingkar, tukang listrik, } \\
\text { pakacca) } \\
\text { Bawah (Tukang tare, }\end{array}$ \\
\hline & & & $\begin{array}{l}\text { tukang bage, tukang } \\
\text { lume) }\end{array}$ \\
\hline $\begin{array}{l}\text { b.Dasar / } \\
\text { ukuran }\end{array}$ & $\begin{array}{l}\text { Kepemilikan, } \\
\text { posisi kerja, } \\
\text { pendapatan }\end{array}$ & $\begin{array}{l}\text { Kepemilikan, } \\
\text { posisi kerja, } \\
\text { pendapatan }\end{array}$ & $\begin{array}{l}\text { Kepemilikan, posisi } \\
\text { kerja, pendapatan }\end{array}$ \\
\hline \multicolumn{4}{|l|}{ Stratifikasi } \\
\hline a Jenis Lapisan & $\begin{array}{l}\text { Atas } \\
\text { (lolo, } \\
\text { kades,imam, } \\
\text { ponggawa) } \\
\text { Bawah } \\
\text { (atta, sawi) }\end{array}$ & $\begin{array}{l}\text { Atas } \\
\text { (lolo,kades,imam, } \\
\text { ponggawa), } \\
\text { Bawah } \\
\text { (atta, sawi, tukang } \\
\text { lume) }\end{array}$ & $\begin{array}{l}\text { Atas } \\
\text { (kades,imam ponggawa), } \\
\text { Menengah } \\
\text { (bas, tukang lingkar, } \\
\text { tukang listrik, pakacca) } \\
\text { Bawah } \\
\text { (tukang tare, }\end{array}$ \\
\hline & & & $\begin{array}{l}\text { tukang bage, tukang } \\
\text { lume) }\end{array}$ \\
\hline $\begin{array}{l}\text { b. Dasar / } \\
\text { ukuran }\end{array}$ & $\begin{array}{l}\text { Kepemilikan } \\
\text { dan } \\
\text { kehormatan } \\
\text { (ascribed and } \\
\text { achieved status) } \\
\end{array}$ & $\begin{array}{l}\text { Kepemilikan dan } \\
\text { kehormatan } \\
\text { (ascribed and } \\
\text { achieved status) }\end{array}$ & $\begin{array}{l}\text { Kepemilikan, posisi } \\
\text { kerja, pendapatan } \\
\text { (achieved status) }\end{array}$ \\
\hline Pola hubungan & $\begin{array}{l}\text { Noneksploitatif, } \\
\text { egaliter }\end{array}$ & $\begin{array}{l}\text { Noneksploitatif, } \\
\text { egaliter }\end{array}$ & $\begin{array}{l}\text { Noneksploitatif, } \\
\text { hirarkis }\end{array}$ \\
\hline $\begin{array}{l}\text { Sistem bagi } \\
\text { hasil }\end{array}$ & $\begin{array}{l}50 \% \text { hasil sawi } \\
\text { diserahkan } \\
\text { pada ponggawa }\end{array}$ & $\begin{array}{l}\text { Potong tengah } \\
\text { (biaya perasional) } \\
50 \% \text { (ponggawa) } \\
50 \%(\text { sawi) }\end{array}$ & $\begin{array}{l}\text { Potong tengah (biaya } \\
\text { operasional) } \\
50 \% \text { (ponggawa): } \\
50 \%(\text { sawi) }\end{array}$ \\
\hline
\end{tabular}

Sementara itu, terjadi pula perubahan kesejahteraan nelayan setiap penggunaan sarana tersebut. Kesejahteraan tersebut berdasarkan indikator pendapatan, pola makan, kondisi rumah, pendidikan, serta cara berpakaian anggota keluarga nelayan. Peningkatan pendapatan tersebut adalah sebagai implikasi dari alih teknologi sarana penangkapan. Penggunaan mesin pada perahu akan memudahkan kelompok nelayan untuk menentukan wilayah tangkapan tanpa 
mempertimbangkan tenaga untuk mendayung. Ukuran perahu yang lebih besar juga memungkinkan kapasitas muatan hasil tangkapan lebih besar. Di samping itu alat tangkap yang lebih modern juga menghasilkan tangkapan yang lebih banyak dibanding sarana sebelumnya. Perubahan pendapatan nelayan dapat dilihat pada tabel berikut.

Tabel 5. Peningkatan Pendapatan Nelayan pada Sarana Tangkap

\begin{tabular}{lccc}
\hline \multirow{2}{*}{ Status Nelayan } & \multicolumn{3}{c}{ Pendapatan pada } \\
& Koli-Koli & Ngkuru-ngkuru & Gae \\
\cline { 2 - 4 } & 111 & 247.7 & 1040 \\
\hline Ponggawa $(\mathrm{n}=45)$ & 47 & 80.6 & 234.1 \\
\hline Sawi Lokal $(\mathrm{n}=30)$ & 46.5 & 84.4 & 232.3 \\
\hline Sawi Luar $(\mathrm{n}=23)$ & &
\end{tabular}

Walaupun terjadi peningkatan pendapatan, berdasarkan metode identifikasi Bangdes, periode penggunaan gae tersebut secara rata-rata nelayan digolongkan pada kelompok masyarakat miskin bagi sawi yakni berpendapatan kurang dari $360 \mathrm{~kg}$ beras. Secara visual dalam hal gaya hidup serta bentuk rumah dan perabot di dalamnya terdapat 25 responden (55.5\%) ponggawa memiliki rumah permanen (dinding tembok) pada rumah di daratan serta 20 (44.4\%) rumah di atas air dengan kontruksi kayu kelas I dan kelas II yang memiliki perabot rumah tangga serta mobiler lainnya. Sedangkan bagi sawi lokal dan luar desa menggunakan rumah konstruksi semipermanen. Semua anggota keluarga nelayan pernah mengenyam pendidikan minimal tingkat SD dan tidak terdapat $(0 \%)$ buta huruf.

\section{Kesimpulan Dan Saran}

\subsection{Kesimpulan}

Penerapan teknologi penangkapan (modernisasi perikanan) dapat diadopsi oleh nelayan Suku Bajo. Namun kecepatan adopsi berbeda-beda sejak teknologi diperkenalkan, dengan interval waktu bagi Pengadopsi Cepat (PC) selama 5-11 tahun Jumlah Pengadopsi Sedang (PS) selama 11-19 tahun dan Pengadopsi Lambat (PL) selama 20-23 tahun. Pengadopsi Cepat (PC) cukup tinggi, selanjutnya berkurang pada Pengadopsi Sedang (PS) dan bertambah lagi pada Pengadopsi Lambat (PL). Secara keseluruhan proses adopsi dapat dikatakan cukup lambat dimana terdapat $66.7 \%$ responden pada katagori PS dan PL dengan waktu adopsi di atas 12 tahun, dibanding waktu mengadopsi di bawah 10 tahun hanya terdapat $33.3 \%$.

Pada pemaknaan laut, kebanyakan responden memberi makna ekonomi, psikologi, dan budaya yang positif. Sedangkan pada makna pekerjaan nelayan kebanyakan responden memberi makna ekonomi, sosiologis, teologis, dan budaya yang cenderung positif. Sementara untuk makna psikologis, sosiologis, dan budaya memperlihatkan tidak ada perbedaan antara ketiga. 
Hubungan antara pemaknaan dan tingkat adopsi digambarkan bahwa semakin positif makna ekonomis maka adopsi inovasi semakin cepat. Sebaliknya semakin positif makna budaya kecenderungan adopsi cenderung semakin lambat.

Penilaian positif pada makna laut lebih pada aspek ekonomis dan budaya. Tingginya persentase penilaian positif makna budaya menunjukan bahwa nelayan masih menempatkan laut dalam kerangka kepentingan nilai-nilai budaya yang sama pentingnya dengan kepentingan ekonomis.

Modernisasi perikanan pada komunitas nelayan membawa dampak pada berbagai segi kehidupan nelayan. Penggunaan setiap jenis sarana tersebut menimbulkan konsekuensi atau dampak yang terjadi yakni pola kerja, struktur sosial, serta tingkat kesejahteraan nelayan.

Pola kerja pada setiap tahap peralihan teknologi dari yang paling sederhana yakni koli-koli, ngkuru-ngkuru sampai pada kapal motor gae menunjukan peningkatan efektifitas dan efisiensi pekerjaan.

Dampak selanjutnya adalah berubahnya struktur sosial nelayan. Perubahan ditandai oleh timbulnya diferensiasi pekerjaan sebagai konsekuensi penggunaan mesin / motor maupun alat tangkap yang lebih modern. Berbagai posisi kerja menyebabkan nelayan terstratifikasi dalam berbagai jenis lapisan. Oleh karena pada beberapa aktivitas penangkapan membutuhkan tenaga kerja yang terampil, maka pembagian kerja (diferensiasi) mulai berlaku. Diferensiasi pekerjaan tersebut menyebabkan pula terjadinya diferensiasi sosial. Diferensiasi sosial nelayan tersebut menyebabkan perubahan struktur sosial dalam kehidupan nelayan. Perubahan tersebut berupa perubahan pola hubungan egaliter menjadi hirarkis tetapi tidak bersifat eksplotatif. Pada sistem stratifikasi, pada konteks komunitas, dasar pelapisan berubah dari ascribed dan achieved status menjadi hanya berdasar achieved status.

Hubungan antara ponggawa sebagai pemilik sarana produksi serta sawi sebagai pekerja bukanlah bersifat eksploitatif, karena di antara mereka masih berlaku nilai-nilai budaya saling membantu baik dalam kelompok kerja maupun kehidupan sehari-hari. Sehingga pola hubungan tidak bersifat eksploitatif serta saling membutuhkan dengan kata lain perbedaan tersebut tidak menunjukan gejala polarisasi oleh karena masih berlakunya tradisi Bajo untuk saling membantu.

\subsection{Saran}

Laut sebagai wilayah open acces serta sumberdaya common property menyebabkan munculnya persaingan antarnelayan, sehingga nelayan kecil menjadi tersingkirkan. Oleh karena itu, dalam hal pemberian bantuan serta program pengembangan masyarakat pantai, pemerintah hendaknya memperhatikan aspek sosial, budaya, serta tingkat kebutuhan nelayan itu sendiri. Pelaksanaan program yang tidak memperhatikan aspek tersebut dapat menyebabkan tujuan program yang tidak tercapai misalnya penolakan untuk mengadopsi, ataupun berdampak pada rusaknya kehidupan sosial nelayan. 
Salah satu aspek yang perlu menjadi bahan pertimbangan pemerintah adalah bagaimana pemerintah mengetahui sejauhmana pemaknaan nelayan tersebut terhadap laut maupun pekerjaannya sebagai nelayan. Program yang berkaitan dengan nelayan adalah sinergi antara aspek ekonomi dan aspek budaya. Hal tersebut disebabkan bahwa pada kelompok nelayan terjadi kecenderungan pergeseran makna ke arah komersil (ekonomis) namun tidak meninggalkan makna budaya. Untuk itu diperlukan interaksi intensif dengan mengikuti tradisi-tradisi komunitas setempat bagi pemerintah secara informal serta meminimalisir "jarak" antara pemerintah dan nelayan.

Selanjutnya oleh karena ketimpangan pendapatan antara nelayan lapisan atas dan lapisan bawah cukup besar, maka perlu adanya kelembagaan sosial (pranata) komunitas dalam hal sistem imbalan antara lapisan atas (ponggawa) dengan lapisan bawah (sawi) sehingga ketimpangan pendapatan pada masingmasing lapisan lebih kecil, serta dapat meredam terjadinya konflik sosial nelayan. Hal tersebut dapat dilakukan dengan membuat aturan bagi hasil maupun sistem imbalan lainnya yang mendapat legalitas dari pemerintah.

Penelitian ini dilakukan pada salah satu komunitas Suku Bajo dengan interaksi sosial dengan suku lainnya cukup sering, di samping mudahnya akses komunikasi dan informasi. Oleh karena itu penelitian selanjutnya sebaiknya pada Suku Bajo, yang masih relatif jauh dengan komunitas suku lain serta terbatasnya akses informasi dan komunikasi. Hal tersebut sangat penting, untuk mengetahui gambaran Suku Bajo yang lebih lengkap.

Dalam hal dampak modernisasi pada kesejahteraan, sebaiknya Analisis lebih tajam dilakukan pada pengeluaran rumah tangga nelayan. Hal tersebut dikaitkan dengan apakah sikap dan perilaku boros yang selama ini menjadi stereotype nelayan terdapat pula pada nelayan Suku Bajo. Analisis pengeluaran tersebut menjadikan katagori kelayakan hidup nelayan lebih terukur.

\section{Daftar Pustaka}

Abernethy, C L. 2002. Water Institution to Enhance Economic Development. Majalah Agricultural + Rural Developmet, No. 2.

Alimuddin, MR. 2005. Orang Mandar Orang Laut. KPG. Jakarta.

Anonim. 1996. Tata Kelakuan Di Lingkungan Keluarga dan Masyarakat Setempat Daerah Sulawesi Tenggara. Depdikbud. Jakarta.

Anonim. 2004. Rakyat Menyemai Jati Pemkab Menuai Hasil: Pengusiran dan Penangkapan Masyarakat Patu-Patu oleh Aparat Kabupaten Muna. http://www.walhi.or.id (21 Februari 2004)

Babbie, E. 2004. The Practice of Social Research. 10 th Edition. Thomson Learning. United States of America.

Dahuri, R. 2000. Pendayagunaan Sumberdaya Perikanan. LISPI. Jakarta. 
Dendi, A, HJ Heile dan A Surahman. 2005. Mengurangi kemiskinan Melalui Pengembangan Ekonomi Kelautan Berkelanjutan Berbasis Kerakyatan. Makalah disampaikan dalam Dialog Pengembangan Ekonomi Lokal Kab. Dompu, 8 Januari 2005.

[Ditjen Perikanan]. 2000. Buku Statistik Perikanan Indonesia. DKP. Jakarta.

Djatmiko, E .1993 Karakteristik dan Permasalahan Pedesaan di Indonesia, dalam Mubyarto (Ed). Dua Puluh Tahun Penelitian Pedesaan. Aditya Media. Yogyakarta.

[DPK Kab.Muna]. 2006. Laporan Kinerja Dinas Perikanan dan Kelautan Kab. Muna tahun 2005. DPK Kab. Mua. Raha.

Hafid Y, P Hamid S Kila, Ansaar. 1996. Pola Pemukiman dan kehidupan Sosial Ekonomi Masyarakat Bajou Daerah Sulawesi Selatan. Depdikbud. Jakarta.

Hayami Y, M Kikuchi. 1981. Dilema Ekonomi Desa. Suatu Pendekatan Ekonomi Terhadap Perubahan Kelembagaan di Asia. YOI. Jakarta.

Ife, J. 1995. An Introduction to Community Work: Creating Community Alternative, Vision, Analysis and Pratice. Longman. Melbourne.

Juwono, PH. 1998. Ketika Nelayan Harus Sandar Dayung. Studi Nelayan Miskin di Desa Kirdowono. Konphalindo. Jakarta.

Kusnadi. 2002. Konflik Sosial Nelayan. Kemiskinan dan Perebutan Sumber Daya Perikanan. LkiS. Yogyakarta.

Kusumastanto, T. 2002. Reposisi Ocean Policy dalam Pembangunan Ekonomi Indonesia di Era Otonomi Daerah. Orasi Ilmiah Guru Besar Tetap Ilmu Kebijakan Ekonomi Perikanan dan Kelautan. FPIK- IPB Bogor.

Kusumastanto T, A. Satria. 2007. Strategi Pembangunan Desa Pesisir Mandiri. Makalah disampaikan pada Semiloka “ Menuju Desa 2030 “, 9-10 Mei 2007.

Lampe, M. 2003. Budaya Bahari dalam Konteks Global dan Modern. Makalah disampaikan pada Seminar kebudayaan nasional, Bukittinggi, 20-23 oktober 2003.

Littlejohn, SW. 1988. Theories of Human Communication Edisi 6. New Mexico Wodworth PC. United States of America.

Masyhuri. 2001. Adaptasi Kelembagaan Ekonomi Masyarakat Nelayan dalam Pemanfaatan Sumberdaya Alam Indonesia. P2E-LIPI. Jakarta.

Masyhuri, M Nadjib. 2000. Pemberdayaan Nelayan Tertinggal: Sebuah Uji Model Penanganan Kemiskinan. PEP- LIPI. Jakarta.

Mead D, MY Lee. 2007. Mapping Indonesian Bajau Communities in Sulawesi. www. SIL-International.com (19 juli 2007) 
Peribadi. 2000. Kedudukan dan Peranan Perempuan Dalam Sistem Kekerabatan Masyarakat Bajo. Tesis Pasca Sarjana. Institut Pertanian Bogor. Bogor.

Prasodjo, NW dan Pandjaitan, NK. 2003. Stratifikasi Sosial dalam Tim Editor, Sosiologi Umum. BISKEM IPB. Wirausaha Muda. Bogor.

Rice, RC. 1991. Environmental Degradation, Pollution, and the Exploitation of Indonesia's Fishery Resources dalam Hardjono, J (Ed), Indonesia: Resources, Ecology and Environment. Oxford University Press. Singapore.

Ritzer G, DJ Godman. 2003. Teori Sosiologi Modern (Terj). Jakarta: Kencana.

Rogers, EM. 1983. Diffusion of Innovation. Third Edition. Macmillan Publishing. New York.

Rusli, S Sumardjo E Soetarto, B Krisnamurti, Y Syaukat, MF Sitorus. 1995. Metodologi Identifikasi Golongan dan Daerah Miskin. Suatu Tinjauan dan Alternatif. Grasindo. Jakarta.

Satria A. 2002. Pengantar Sosiologi Masyarakat Pesisir. Jakarta: Cidesindo.

Siahaan, H. 1996. Struktur Sosial dan Kemisikinan Petani dalam Alfian (ed), Kemiskinan Struktural: Suatu Bungan Rampai. YIIS. Jakarta.

Siregar, BB. 2001. Menelusuri Jejak Ketertinggalan. Merajut Kerukunan Melintasi Krisis. Pusat P3R-YAE. Bogor.

Soemardjan, S \& Breazeale, K. 1993. Cultural Change in Rural Indonesia: Impact of Village Development. Sebelas Maret University Press-YIIS East-West Center Honolulu. Surakarta-Indonesia.

Solihin, A. 2005 Merancang Revitalisasi Perikanan. www.penulislepas.com (18 September 2005)

Suhartini A, Halim, I Hambali, A Basyid (Eds). 2005. Model - Model Pemberdayaan Masyarakat. Lkis. Yogyakarta.

Suwarsono, So, AY 2000. Perubahan Sosial dan Pembangunan di Indonesia. Penerbit LP3ES. Jakarta.

Syahyuti. 2003. Alternatif Konsep Kelembagaan untuk Penajaman Operasionalisasi dalam Penelitian Sosiologi. Forum Penelitian Agroekonomi. Vol 21 no. 2.

Wahyono, A, IGP Antaraiksa, M Imran, R. Indrawasih, Sudiyono. 2001. Pemberdayaan Masyarakat Nelayan. Media Pressindo. Jakarta.

Wahyono A, AR Patji, DS Laksono, R Indrawarsih, Sudiyono, S Ali. 2000. Hak Ulayat Laut di Kawasan Timur Indonesia. Media Pressindo. Jakarta.

Wariyanto, A. 2004. Perlu Pemberdayaan Nelayan. http://www.kalyanamitra.or.id (10 April 2004) 
Winahyu, Santiasi. 1993. Pengembangan Desa Pantai, dalam Mubyarto dkk, Dua Puluh Tahun Penelitian Pedesaan. Aditya Media. Yogyakarta.

Wirutomo, P. 2005. Mencari Format Pembangunan Berbasis Nilai (Furnal Sosiologi Indonesia No.7/2005).

Yudana, IW, DA Budiari, I. A Wikanta,. 1993. Pengaruh Modernisasi Terhadap Organisasi Sosial (Studi Kasus Nelayan desa Serangan Bali). FISIP Unud. Denpasar 
